\title{
Rare earth element geochemistry of spring water, north western Bam, NE Iran
}

\author{
Kaveh Pazand • Ali Reza Javanshir
}

Received: 18 March 2013/Accepted: 27 August 2013/Published online: 7 September 2013

(C) The Author(s) 2013. This article is published with open access at Springerlink.com

\begin{abstract}
In this paper, based on the analysis of major ions and rare earth elements (REEs), spring water samples from the north western Bam area, central Iran were investigated for the hydrochemical processes, geochemical behavior of REEs and ion concentration background in the region. In the study area, the order of cation and anion abundance is $\mathrm{Na}^{+}>\mathrm{K}^{+}>\mathrm{Mg}^{2+}>\mathrm{Ca}^{2+}$ and $\mathrm{Cl}^{-}>$ $\mathrm{SO}_{4}^{-2}>\mathrm{HCO}_{3}{ }^{-}>\mathrm{NO}_{3}{ }^{-}$, and the dominated hydrochemical water are of $\mathrm{Na}-\mathrm{Cl}$ type. The groundwater shows heavy REEs enrichment relative to light REEs. Depending on water types, REEs show different behaviors in study area. The increase in TDS and Fe contents in groundwater is accompanied by an increase in REE concentrations, while an increase in $\mathrm{pH}$ and Eh values is accompanied by a decrease in REE concentrations. Moreover, correlation analysis indicates that $\mathrm{Eh}-\mathrm{pH}$ condition, TDS and $\mathrm{Fe}$ content, aquifer rock as well as their minerals play an important role in controlling the REE enrichment of groundwater.
\end{abstract}

Keywords REE - Groundwater - Bam · Hydrogeochemical processes

K. Pazand ( $\square)$

Department of Mining Engineering, Science and Research

Branch, Islamic Azad University, Tehran, Iran

e-mail: kaveh.pazand@gmail.com

A. R. Javanshir

Department of Geology, Tarbiat Modares University,

Tehran, Iran

\section{Introduction}

Rare earth elements (REEs) are of great interest for many scientists because of their unique characteristics and will be used in the study of many geological processes (Bau 1991; Leybourne et al. 2000; Herong et al. 2011). Ample evidence has been already provided to show that REEs could be much mobilized during weathering, alteration and diagenetic processes and then leading to extensive fractionation between REEs (Wood 1990; Seto and Akagi 2008).

Recent research has also explored REE behavior in different groundwater environments. Using REEs for tracing groundwater flow is a relatively recent approach. Behavior of the REEs with their sensitivity to $\mathrm{pH}$, redox conditions and adsorption/desorption reactions are particularly useful in hydrogeochemical studies (Wood 1990; Tang and Johannesson 2006; Guo et al. 2010; willis and Johannesson 2011). In addition, because the REEs typically behave coherently, perturbations from the expected patterns can yield critical information on the types of processes occurring within a water-rock system (Guo et al. 2010; Esmaeili-Vardanjani et al. 2012).

In this study, we investigate the geochemical behavior of REEs within the groundwater of north western Bam City, where a typical sediment-filled basin (NE Iran) is present. Also, we will discuss chemical processes, which may control REE concentrations in groundwater.

\section{Study area}

The study area is located within the Bam Plain in the south eastern Iran (Fig. 1). The topography of the study area is a mixture of rugged mountains with flat plains. The area has a hot temperate climate, with mean maximum summer 


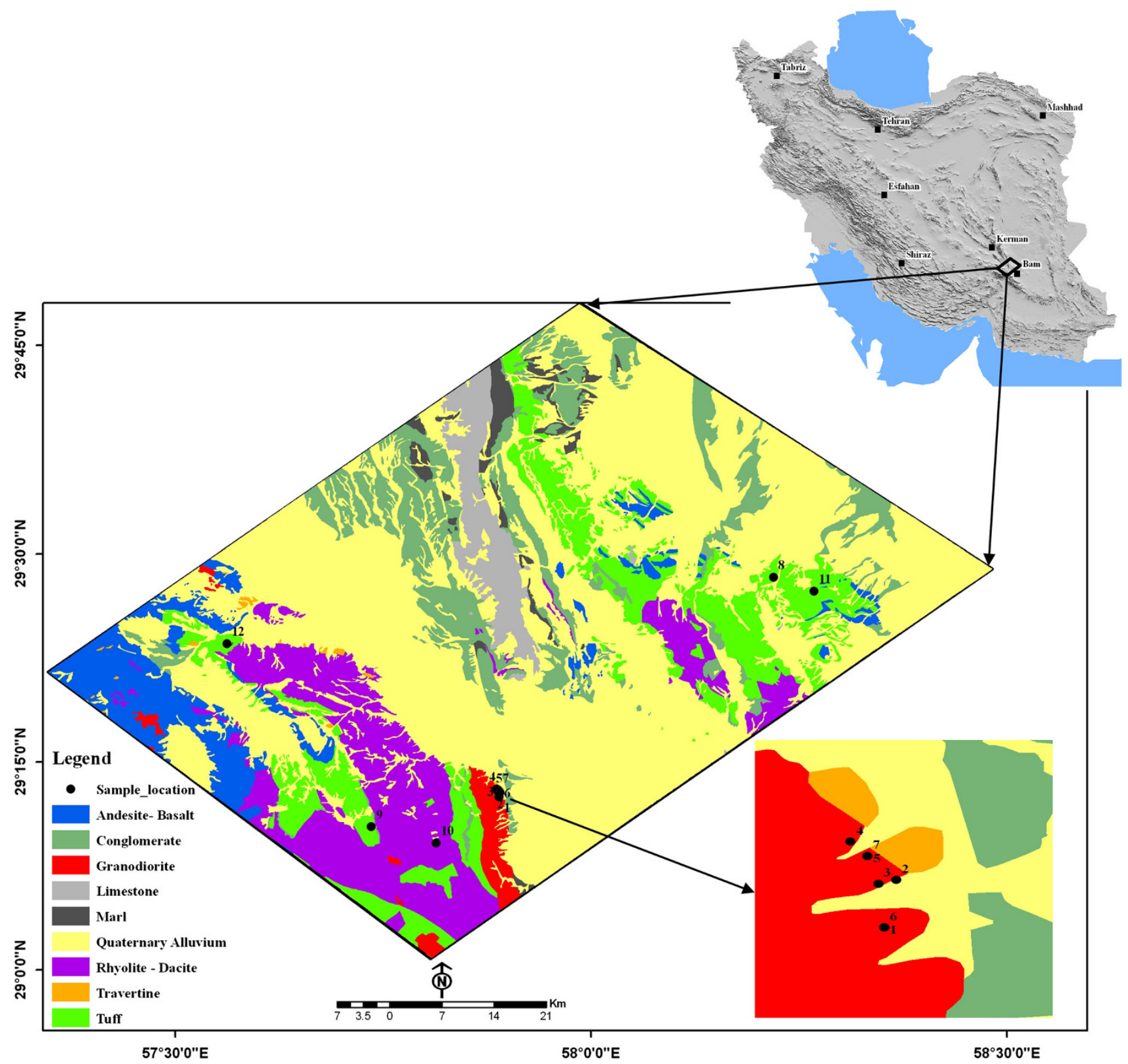

Fig. 1 Map showing sample location and surface geochemistry of the study area (after Aghanabati 1993)

temperatures (July) of about $45^{\circ} \mathrm{C}$ and minimum winter temperatures (January) of $15^{\circ} \mathrm{C}$. The climate of the study area is considered to be arid with annual precipitation being approximately $100 \mathrm{~mm}$.

The plain consists of a Quaternary alluvium that is confined by the Miocene conglomerate, Oligocene tuff, Eocene volcanic rocks and Paleogene granodiorite (Aghanabati 1993). The igneous rocks (acid-alkali) are formed mostly around Bam Plain and in some areas such as in the north and east parts, sedimentary formations such as limestone, marl and conglomerate are seen. In the central, eastern and southern parts of the region are the alluvial fans, which are well composed of coarse alluvial material and gradually become fine-grained toward the north and north east (Khademi 1984). Acidic tuffs are common in the region. The travertine in the study area belongs to the volcanic rocks, extending from the west of the study area (Fig. 1).

Travertine is defined as a chemically precipitated continental limestone formed around seepage, springs and along streams and rivers, occasionally in lakes and consists of calcite or aragonite, of low to moderate intercrystalline porosity and often high mouldic or framework porosity within a vadose or occasionally shallow phreatic environment (Keshavarzi et al. 2011). 


\section{Groundwater sampling and analysis}

Groundwater samples were collected from 12 springs within the study area in December, 2011. They were stored in $100 \mathrm{ml}$ polyethylene bottles. $\mathrm{pH}$, specific conductance, temperature, dissolved oxygen concentration and Eh were determined using a multi-parameter portable meter (HATCH, Germany). At each site, the $\mathrm{pH}$ electrode was calibrated using two buffers (Merck, Germany) that bracketed the measured $\mathrm{pH}$ and that were thermally equilibrated with the water sample.

Titrations were performed to analyze total alkalinity $\left(\mathrm{HCO}_{3}{ }^{-}+\right.$minor $\left.\mathrm{CO}_{3}{ }^{2-}\right)$ and ion chromatography for anions $\left(\mathrm{Cl}^{-}, \mathrm{NO}_{3}{ }^{-}, \mathrm{SO}_{4}{ }^{2-}\right)$. Cations, $\mathrm{REE}$ and other major and trace elements were measured by inductively coupled plasma and mass spectrometry (ICP-MS) in the filtered and acidified water samples within 2 weeks after sampling (Table 1).

\section{Hydrochemical characteristics of groundwater}

The chemical compositions of the groundwater samples are statistically analyzed and the results are given in Table 1.

The $\mathrm{pH}$ of the groundwater in the study area ranged from 7.4 to 8.33 with an average value of 7.70 , indicating an alkaline nature of the samples. The Eh can be used to find out the relative redox conditions of an aquifer (Smedley and Edmunds 2002). Eh in the study area ranged from 4.2 to $72.9 \mathrm{mV}$ and therefore weak oxidization to reducing conditions prevail in the area. Total dissolved solid (TDS) is an important parameter that can be used to observe the influence of major components in groundwater quality, and as a function of mineralization characteristics of the groundwater, the TDS of the groundwater samples range from 168 to $18,690 \mathrm{mg} / \mathrm{l}$, with a mean value of $13,524 \mathrm{mg} / \mathrm{l}$.

The relative content of a cation or an anion is defined as the percentage of the relative amount of that ion to the total cations or anions, respectively (Pazand et al. 2012). The concentrations of $\mathrm{Ca}^{2+}, \mathrm{Mg}^{2+}, \mathrm{Na}^{+}$and $\mathrm{K}^{+}$ represent on average $1.81,2.53,88.82$ and $6.84 \%$ of the cations, respectively. Among the anions, the concentrations of $\mathrm{HCO}_{3}^{-}, \mathrm{Cl}^{-}, \mathrm{NO}_{3}^{-}$and $\mathrm{SO}_{4}^{-2}$ represent on average $8.38,52.8,4.96$ and $33.86 \%$, respectively. Thus, the order of cation and anion abundance is $\mathrm{Na}^{+}>\mathrm{K}^{+}>\mathrm{Mg}^{2+}>\mathrm{Ca}^{2+}$ and $\mathrm{Cl}^{-}>\mathrm{SO}_{4}^{-2}>\mathrm{HCO}_{3}{ }^{-}$ $>\mathrm{NO}_{3}{ }^{-}$, respectively. The hydrochemical facies is used to describe the bodies of groundwater in an aquifer that differ in their chemical composition. The facies are a function of the lithology, solution kinetics, and flow patterns of the aquifer. A scatter distribution of groundwater samples on Piper diagram shows three water types for the water samples (Fig. 2): $\mathrm{Na}-\mathrm{Cl}, \mathrm{Na}-$ $\mathrm{HCO}_{3}$ and $\mathrm{Na}-\mathrm{Mg}-\mathrm{HCO}_{3}-\mathrm{Cl}$ that represent 66.66, 16.67 and $16.67 \%$ of the total number of water samples, respectively.

Most metal concentrations in water depend on the mineral solubility, $\mathrm{pH}$, Eh and salinity of the solution. Copper concentrations are in the range of $0.2-94 \mu \mathrm{g} / \mathrm{l}$, whereas $\mathrm{Pb}$ concentrations are $<0.1-9.9 \mu \mathrm{g} / \mathrm{l}$ and concentrations of $\mathrm{Zn}$ show variation between 0.7 and $108.5 \mu \mathrm{g} / \mathrm{l}$. Total $\mathrm{Fe}$ concentrations range from $<0.01$ to $0.07 \mathrm{mg} / \mathrm{l}$ (Table 1). The highest $\mathrm{Fe}$ concentrations (0.07 and $0.06 \mathrm{mg} / \mathrm{l}$ ) occurred at the eastern part of the area and were detected in wells 8 and 11 . The Mo, V and Se concentrations ranged from 1.3 to $47.4,0.4$ to 54.1 and $<0.5$ to 414 , respectively.

Table 1 Statistical summary of the chemical characteristics of groundwater of the study area

\begin{tabular}{|c|c|c|c|c|c|c|c|c|c|c|c|c|c|c|}
\hline Parameter & $\mathrm{pH}$ & $\begin{array}{l}\text { Eh } \\
\mathrm{mV}\end{array}$ & $\begin{array}{l}\mathrm{O}_{2} \\
\mathrm{mg} / \mathrm{l}\end{array}$ & $\begin{array}{l}\mathrm{EC} \\
\mu \mathrm{S} / \mathrm{cm}\end{array}$ & $\begin{array}{l}\text { TDS } \\
\mathrm{mg} / \mathrm{l}\end{array}$ & $\begin{array}{l}\mathrm{Cl} \\
\mathrm{mg} / \mathrm{l}\end{array}$ & & $\begin{array}{l}\mathrm{NO}_{3} \\
\mathrm{mg} / \mathrm{l}\end{array}$ & $\begin{array}{l}\mathrm{SO}_{4} \\
\mathrm{mg} / \mathrm{l}\end{array}$ & $\begin{array}{l}\mathrm{HCO}_{3} \\
\mathrm{mg} / \mathrm{l}\end{array}$ & $\begin{array}{l}\mathrm{Ca} \\
\mathrm{mg} / \mathrm{l}\end{array}$ & $\begin{array}{l}\mathrm{Mg} \\
\mathrm{mg} / \mathrm{l}\end{array}$ & $\begin{array}{l}\mathrm{K} \\
\mathrm{mg} / \mathrm{l}\end{array}$ & $\begin{array}{l}\mathrm{Na} \\
\mathrm{mg} / \mathrm{l}\end{array}$ \\
\hline $\operatorname{Max}$ & 8.33 & 72.90 & 13.81 & 116,100 & 18,690 & 68,59 & .00 & $2,625.00$ & $33,734.00$ & $5,350.00$ & 604.00 & 912.00 & 3510.00 & 16400.00 \\
\hline Min & 7.04 & 4.20 & 0.39 & 30 & 169 & & 28 & 2.50 & 4.24 & 140.00 & 14.70 & 4.28 & 0.74 & 49.10 \\
\hline Average & 7.70 & 37.05 & 7.70 & 14,538 & 13,524 & 12,26 & .59 & $1,380.07$ & $7,867.72$ & $1,943.13$ & 147.49 & 201.26 & 548.51 & 7121.63 \\
\hline Standard deviation & 0.48 & 23.29 & 3.75 & 33,149 & 6,829 & 18,55 & .19 & $1,226.37$ & $10,127.84$ & $1,624.84$ & 209.82 & 263.92 & 950.61 & 4518.17 \\
\hline Parameter & $\begin{array}{l}\mathrm{Cr} \\
\mu \mathrm{g} / 1\end{array}$ & $\begin{array}{l}\mathrm{Cu} \\
\mu \mathrm{g} / \mathrm{l}\end{array}$ & & $\begin{array}{l}\mathrm{Fe} \\
\mathrm{ng} / \mathrm{l}\end{array}$ & $\begin{array}{l}\mathrm{Mn} \\
\mathrm{ag} / \mathrm{l}\end{array}$ & $\begin{array}{l}\text { Mo } \\
\mu \mathrm{g} / \mathrm{l}\end{array}$ & $\begin{array}{l}\mathrm{Ni} \\
\mu \mathrm{g} / \mathrm{l}\end{array}$ & $\begin{array}{l}\mathrm{Pb} \\
\mu \mathrm{g} / 1\end{array}$ & $\begin{array}{l}\mathrm{Sb} \\
\mu \mathrm{g} / 1\end{array}$ & $\begin{array}{l}\mathrm{Se} \\
\mu \mathrm{g} / 1\end{array}$ & $\begin{array}{l}\mathrm{Sr} \\
\mu \mathrm{g} / 1\end{array}$ & $\begin{array}{l}\mathrm{V} \\
\mu \mathrm{g} / 1\end{array}$ & $\begin{array}{l}\mathrm{Zn} \\
\mu \mathrm{g} / \mathrm{l}\end{array}$ & $\begin{array}{l}\mathrm{Zr} \\
\mu \mathrm{g} / 1\end{array}$ \\
\hline Max & 0.01 & 94.0 & & 0.07 & 33.79 & 47.40 & 42.70 & 9.90 & 43.64 & 414.00 & 24.71 & 54.10 & 108.50 & 762 \\
\hline Min & 0.00 & 0.2 & 20 & $<0.01$ & $<0.05$ & 1.30 & 0.90 & $<0.1$ & 0.99 & $<0.5$ & 0.06 & 0.40 & 0.70 & 0.17 \\
\hline Average & 0.00 & 18.1 & & 0.03 & 6.47 & 26.28 & 9.76 & 1.78 & 20.95 & 118.66 & 16.24 & 25.82 & 26.23 & 77.56 \\
\hline Standard deviation & 0.00 & 30.9 & & 0.03 & 11.77 & 15.08 & 12.62 & 3.98 & 17.70 & 121.71 & 9.06 & 24.92 & 32.46 & 240.49 \\
\hline
\end{tabular}




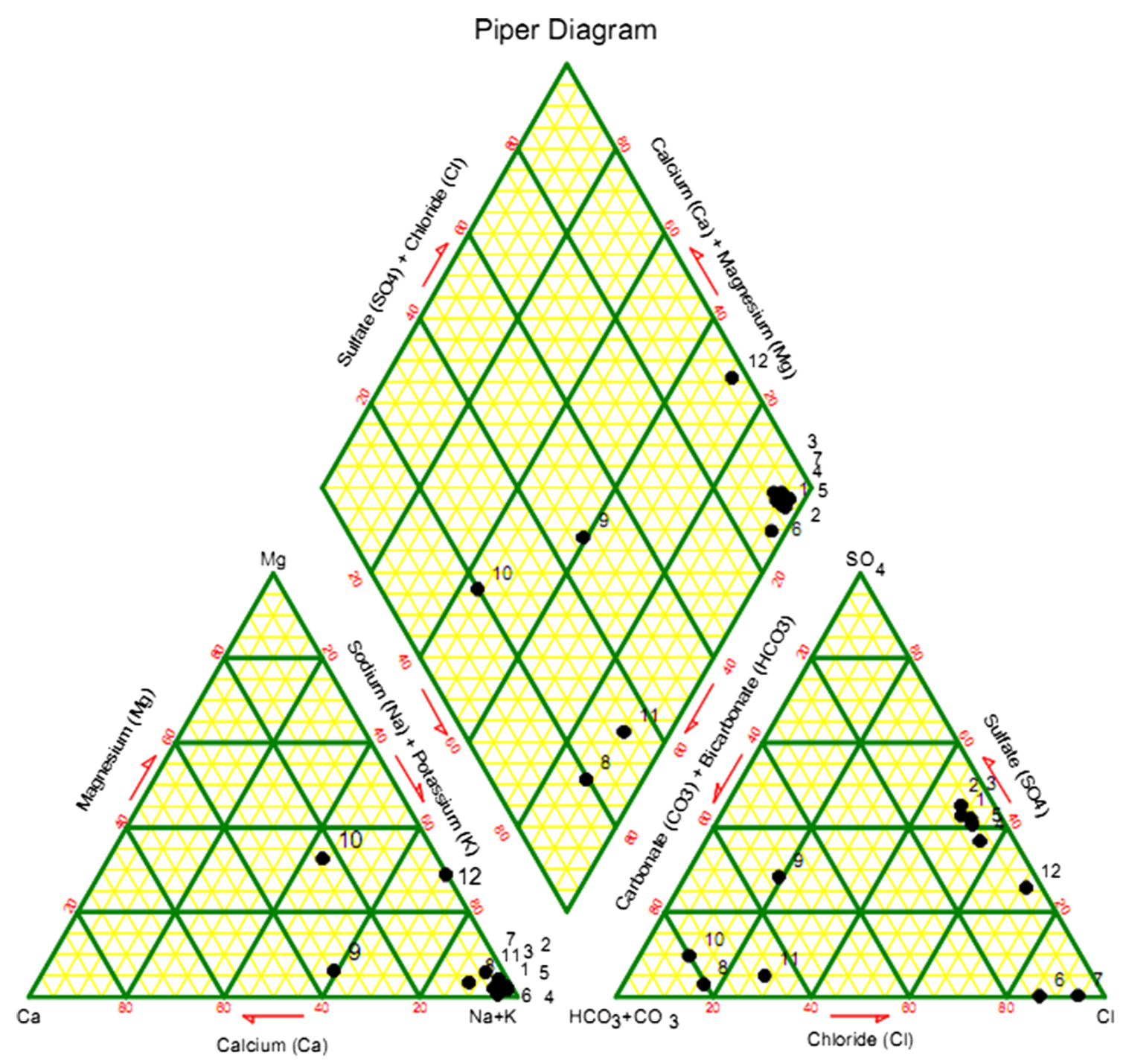

Fig. 2 The Piper diagram for the groundwater samples of the study area

\section{REE concentrations}

Rare earth element concentrations in the study area vary with the total REE concentrations ranging from $0.17 \mu \mathrm{g} / \mathrm{l}$ (spring 9) to $8.36 \mu \mathrm{g} / \mathrm{l}$ (sample 12) (Table 2).

Many studies have shown that $\mathrm{pH}$ can play an important role in controlling the mobility of REEs, and higher REE concentrations are typically associated with lower $\mathrm{pH}$ values (Keasler and Loveland 1982; Tang and Johannesson 2006; Guo et al. 2010). Although there is considerable scatter, the $\Sigma$ REE of the groundwater samples in this study negatively correlated with their $\mathrm{pH}$ values (Fig. 3). The measured Eh can be used with other redox indicators to determine, in a qualitative sense, the relative redox conditions of an aquifer (Smedley and Edmunds 2002). Figure 3 shows that an increase in REE concentration occurs in phase with a decline in the redox potential. The $\Sigma$ REE concentrations in groundwater show a good positive correlation with the TDS contents indicating that $\Sigma$ REE concentrations are well related to salinity of the water samples (Fig. 3). Dissolved Fe concentrations correlate with $\Sigma$ REE. Hence, reduction of Fe hydroxides would be the reason for the raised REE concentrations of the groundwater from this area.

\section{REE fractionation}

In order to best evaluate the geochemical processes responsible for fractionation of the REE in natural waters, it is most appropriate to normalize the waters to the rocks with which they react. In fact, natural waters may react with many rock types that have different REE signatures. Hence, it is impossible to develop normalizing standard for every system under study (Nguyet 2006).

Normalized patterns with respect to the estimated average composition of the North American Shale 
Table 2 Rare earth element concentrations of groundwater samples $(\mu \mathrm{g} / \mathrm{l})$

\begin{tabular}{llllllllllllllllllll}
\hline Samples & $\mathrm{La}$ & $\mathrm{Ce}$ & $\mathrm{Pr}$ & $\mathrm{Nd}$ & $\mathrm{Sm}$ & $\mathrm{Eu}$ & $\mathrm{Gd}$ & $\mathrm{Tb}$ & $\mathrm{Dy}$ & $\mathrm{Ho}$ & $\mathrm{Er}$ & $\mathrm{Tm}$ & $\mathrm{Yb}$ & $\mathrm{Lu}$ & $\Sigma \mathrm{REE}$ & $\mathrm{Ce} / \mathrm{Ce} *$ & $\mathrm{Eu} / \mathrm{Eu}{ }^{*}$ & $\mathrm{Gd} / \mathrm{Gd} *$ \\
\hline 1 & 0.01 & 0.03 & - & 0.25 & 0.01 & 0.02 & 0.21 & - & - & - & - & - & 0.02 & - & 0.55 & 1.32 & 0.0025 & 0.96 \\
2 & 0.01 & 0.05 & - & 0.17 & 0.01 & 0.02 & 0.24 & - & - & - & - & - & 0.01 & - & 0.51 & 2.19 & 0.0023 & 0.96 \\
3 & 0.01 & 0.05 & - & 0.17 & 0.01 & 0.02 & 0.24 & - & - & - & 0.01 & - & 0.01 & - & 0.52 & 2.19 & 0.0023 & 0.96 \\
4 & - & 0.04 & - & 0.19 & 0.01 & 0.02 & 0.2 & - & - & - & 0.01 & - & 0.01 & - & 0.48 & & 0.0025 & 0.96 \\
5 & 0.01 & 0.04 & - & 0.16 & 0.02 & 0.01 & 0.12 & - & - & - & - & - & 0.01 & - & 0.37 & 1.75 & 0.0016 & 0.87 \\
6 & 0.02 & 0.02 & - & 0.18 & 0.02 & 0.02 & 0.33 & - & - & - & - & - & 0.03 & - & 0.62 & 0.44 & 0.0020 & 0.95 \\
7 & 0.01 & 0.01 & - & 0.08 & 0.03 & 0.02 & 0.26 & - & 0.02 & - & - & 0.01 & 0.03 & 0.01 & 0.48 & 0.44 & 0.0022 & 0.90 \\
8 & 0.11 & 0.13 & 0.03 & 0.22 & 0.04 & 0.03 & 0.23 & 0.01 & 0.03 & - & - & - & - & - & 0.83 & 0.25 & 0.0034 & 0.86 \\
9 & - & 0.01 & - & 0.01 & 0.04 & 0.01 & 0.04 & - & 0.05 & - & 0.01 & - & - & - & 0.17 & & 0.0021 & 0.52 \\
10 & - & 0.05 & - & - & 0.05 & 0.01 & 0.06 & - & - & - & 0.05 & - & 0.01 & 0.01 & 0.24 & & 0.0018 & 0.57 \\
11 & 0.19 & 0.18 & 0.05 & 0.35 & 0.22 & 0.06 & 0.4 & 0.04 & 0.13 & 0.04 & 0.09 & 0.02 & 0.11 & 0.02 & 1.90 & 0.20 & 0.0045 & 0.67 \\
12 & 0.41 & 2.34 & 0.15 & 2.44 & 0.46 & 0.12 & 0.64 & 0.08 & 0.37 & 0.37 & 0.42 & 0.08 & 0.4 & 0.08 & 8.36 & 1.01 & 0.0068 & 0.60 \\
\hline
\end{tabular}

Below detection limits $(<0.01 \mu \mathrm{g} / \mathrm{l})$
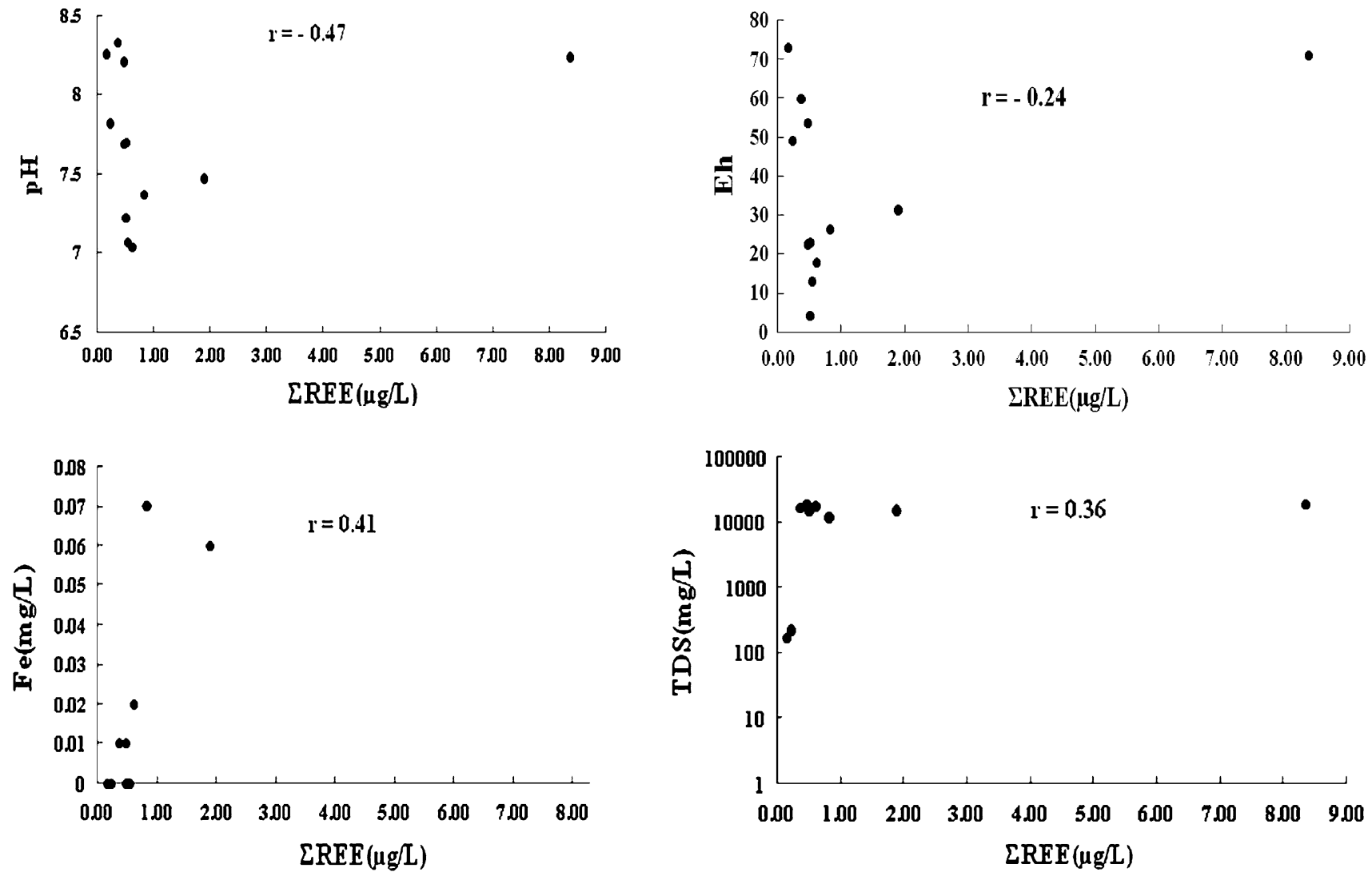

Fig. 3 Relationships among pH, Eh, Fe, TDS and REE in the study area

Composite (NASC) (Taylor and McLennan 1985) that has been employed recently in groundwater studies (Leybourne et al. 2000; Rönnback et al. 2008; Guo et al. 2010) are shown in Fig. 4 for groundwater in this study.

The groundwater samples mostly exhibit enrichment in the high REE (HREE) relative to the light REE (LREE)
(Fig. 4). This can be explained by the differences in geochemical mobility between LREE and HREE during water-rock interaction. The groundwater samples have three different shale-normalized REE patterns.

Type 1: Samples 8 and $11\left(\mathrm{Na}-\mathrm{HCO}_{3}\right.$ type) have substantial negative, shale-normalized $\mathrm{Ce}$ anomalies $(\mathrm{Ce} /$ 
Fig. 4 Shale-normalized REE patterns for groundwater of the study area; a sample 12,

b samples 8 and 11, c other samples
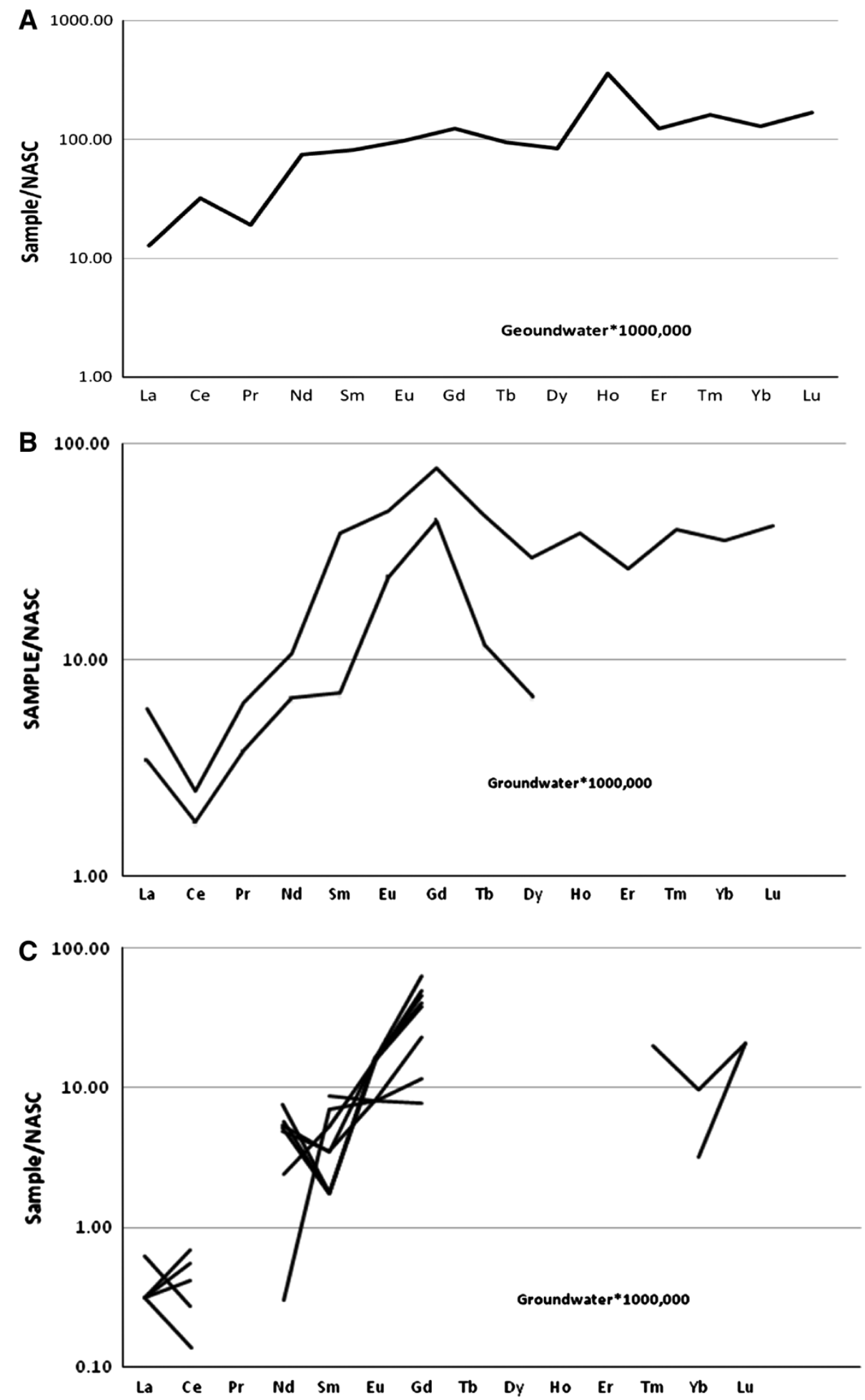

$\mathrm{Ce}^{*}=0.25$ and 0.2 , respectively), low positive $\mathrm{Eu}$ anomalies $\left(\mathrm{Eu} / \mathrm{Eu}^{*}=0.0034\right.$ and 0.0045 , respectively) and low positive $\mathrm{Gd}$ anomalies $\left(\mathrm{Gd} / \mathrm{Gd}^{*}=0.86\right.$ and 0.67 , respectively).

The negative $\mathrm{Ce}$ anomalies may reflect oxidative conditions of the aquifer, whereby $\mathrm{Ce}^{3+}$ is oxidized to the less soluble $\mathrm{Ce}^{4+}$ because of their positive Eh values (Table 1). It is also shown in Fig. 5 that $\mathrm{Eu} / \mathrm{Eu}^{*}$ ratios are positively correlated with Eh and $\mathrm{pH}$ values, suggesting that redox condition and $\mathrm{pH}$ are responsible for the positive $\mathrm{Eu}$ anomalies. The reason for Eu enrichment in the groundwater of the study area would be the preferential 


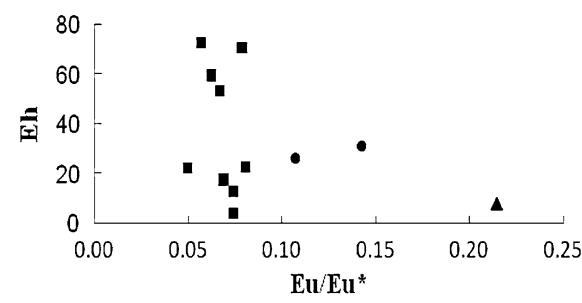

- sample 8 and 11

-other sample

¿Sample 12

- sample 8 and 11

vother sample

\sample12

- sample 8 and 11

other sample

$\Delta$ sample12

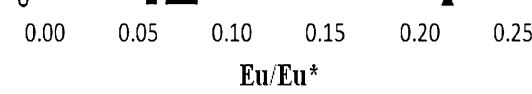

Eu/Eu*

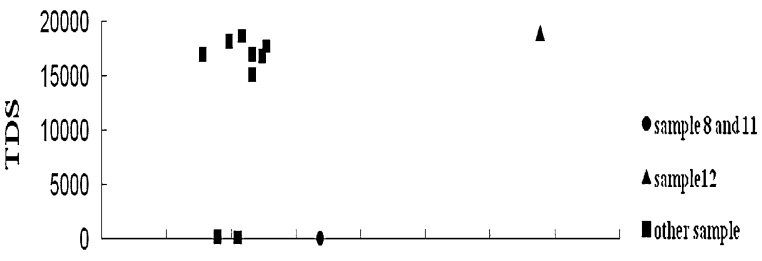

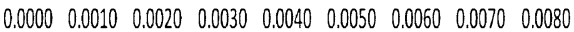

$\mathrm{Eu} / \mathrm{Eu}{ }^{*}$

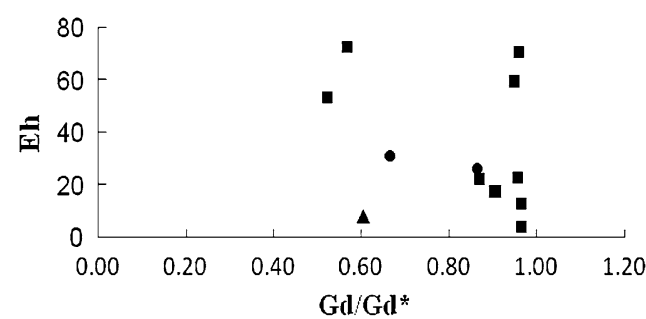

- sample 8 and 11

-other sample

ASample 12

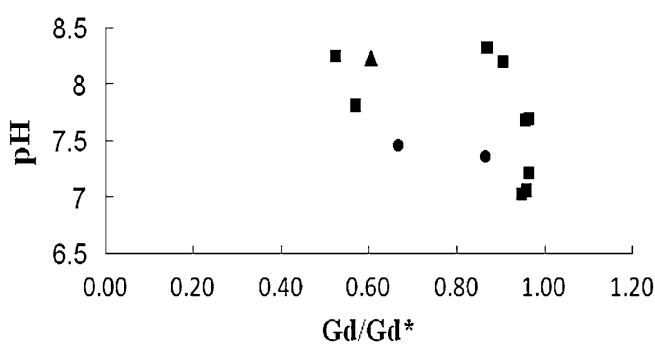

- sample 8 and 11

other sample

$\Delta$ sample12

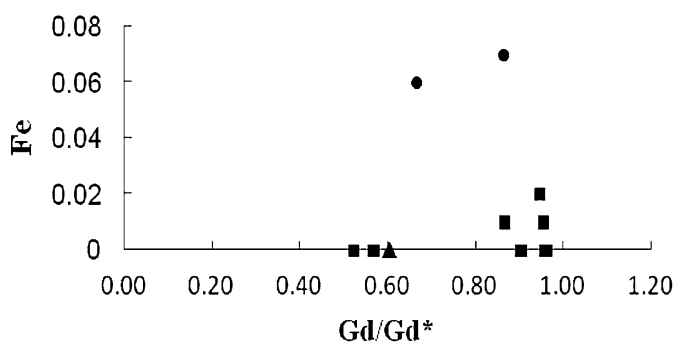

- sample 8 and 11

other sample

$\Delta$ sample12

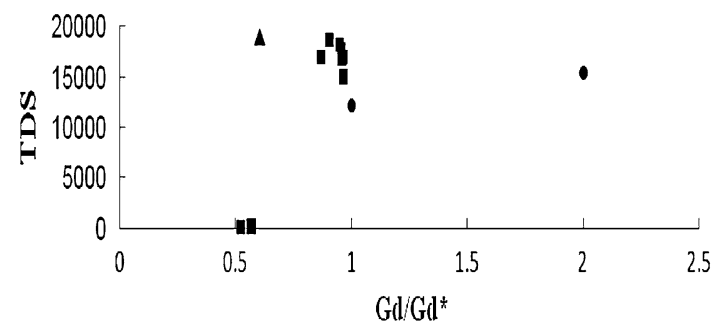

- sample 8 and 11

Asample12

uother sample

Fig. 5 Relationships among $\mathrm{Eu} / \mathrm{Eu}^{*}$ and $\mathrm{Gd} / \mathrm{Gd}^{*}$ ratios and $\mathrm{Eh}, \mathrm{pH}, \mathrm{Fe}$, TDS values in groundwater of the study area

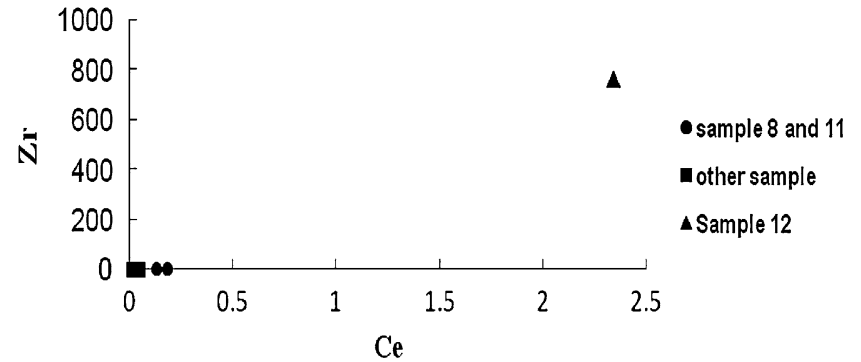

Fig. 6 Relationships among $\mathrm{Zr}$ and $\mathrm{Sr}$ with $\mathrm{Ce}$ values in groundwater

mobilization of $\mathrm{Eu}^{2+}$ relative to the more particle-reactive trivalent REE and must be related to plagioclase in the magmatic rocks.

Gadolinium anomalies are known in groundwater, but these are small and appear to be restricted to seawater and

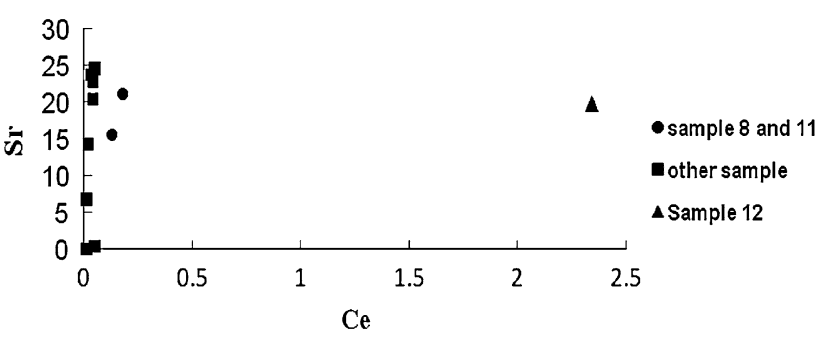

some groundwater, and to precipitates from those. The large size of the positive anomalies reported for $\mathrm{Gd}$ in some river waters, therefore, rules out any possibility that they result from natural REE fractionation (Kualaksi and Bau 2007). In $\mathrm{Na}-\mathrm{HCO}_{3}$-type water, $\mathrm{Gd}$ anomalies have 
negative correlation with $\mathrm{pH}-\mathrm{Eh}$ values and show converse treatment with Eu anomalies (Fig. 5).

Type 2: Sample 12 has a positive shale-normalized Ce anomaly $\left(\mathrm{Ce} / \mathrm{Ce}^{*}=1.01\right)$ and a positive Ho anomaly. The rocks as well as their minerals play an important role in controlling the fractionation of REE in groundwater, in which case they might be also important in controlling $\mathrm{Ce}$ anomalies (Herong et al. 2011). The correlation coefficients of $\mathrm{Sr}, \mathrm{Zr}$ versus Ce shown in Fig. 6 indicate that in sample $12, \mathrm{Zr}$ and $\mathrm{Sr}$ have very high concentration; therefore, plagioclase and zircon are important in controlling the Ce anomaly in this sample.

Type 3: In other samples, Ce and Eu contents are low and other REEs generally below the detection limits of $\Sigma$ REE vary from 0.17 to $0.62 \mu \mathrm{g} / \mathrm{l}$ (Table 2 ). The clear correlation between the $\mathrm{Ce}, \mathrm{Eu}$ and $\mathrm{Gd}$ anomalies with $\mathrm{pH}-$ Eh, TDS and Fe cannot be seen (Fig. 5).

\section{Conclusions}

In this paper, we examined the chemical process of spring water in the study area for the first time and the geochemical behavior of REE has been studied, which could be the basis for future studies and management of water resources in the region, where because of climatic conditions available water resources are important.

Rare earth element concentrations are highly variable in springs of the north western of Bam, with generally higher REE contents typical of waters with higher Fe-TDS and lower $\mathrm{pH}-\mathrm{Eh}$. The major cations in the studied groundwater are in the decreasing order of $\mathrm{Na}^{+}>\mathrm{K}^{+}>\mathrm{Mg}^{2+}>\mathrm{Ca}^{2+}$ and the anions are also in the decreasing order of $\mathrm{Cl}^{-}>\mathrm{SO}_{4}^{-2}>\mathrm{HCO}_{3}{ }^{-}>\mathrm{NO}_{3}{ }^{-}$. In general, the main hydrochemical facies of groundwater from the studied area are of $\mathrm{Na}+\mathrm{Cl}, \mathrm{Na}+\mathrm{HCO}_{3}$ and $\mathrm{Na}+\mathrm{HCO}_{3}+\mathrm{Cl}+\mathrm{Mg}$ types. The increase in TDS and Fe contents in groundwater is accompanied by an increase in REE concentrations, whereas an increase in $\mathrm{pH}$ and $\mathrm{Eh}$ values is accompanied by a decrease in REE concentrations. Although groundwater shows HREE enrichment relative to LREE in samples, evidence suggests that REE concentrations and patterns predominantly show differences in waters. In $\mathrm{Na}+\mathrm{HCO}_{3}$ type, it has negative $\mathrm{Ce}$ but positive $\mathrm{Eu}$ and $\mathrm{Gd}$ anomalies. The $\mathrm{Eu} / \mathrm{Eu}^{*}$ ratio has a positive correlation with $\mathrm{Eh}$ and $\mathrm{pH}$ values and negative correlation with $\mathrm{Fe}$ concentration, while this correlation is reversed for the $\mathrm{Gd} / \mathrm{Gd}^{*}$ ratio. The groundwater of sample 12 has positive shale-normalized Ce anomaly, and plagioclase and zircon are important in controlling the $\mathrm{Ce}$ anomaly in this sample. In other samples, $\mathrm{Ce}$ and $\mathrm{Eu}$ contents have low $\Sigma$ REE varying from 0.17 to $0.62 \mu \mathrm{g} / \mathrm{l}$, and a clear correlation between the $\mathrm{Ce}, \mathrm{Eu}$ and Gd anomalies with $\mathrm{pH}-\mathrm{Eh}$, TDS and Fe cannot be seen.
Moreover, correlation analysis indicates that Eh-pH condition, TDS and Fe content, aquifer rock, as well as their minerals play an important role in controlling the REE enrichment of groundwater. Due to the similarity of REE between aquifer rock and groundwater, as well as the differences of rock types beyond the aquifers, REEs thus can be considered useful in discriminating between water sources.

Open Access This article is distributed under the terms of the Creative Commons Attribution License which permits any use, distribution, and reproduction in any medium, provided the original author(s) and the source are credited.

\section{References}

Aghanabati A (1993) Geology map of Rayen 1:250000 sheets. Geological Survey of Iran

Bau M (1991) Rare-earth element mobility during hydrothermal and metamorphic fluid-rock interaction and the significance of the oxidation state of europium. Chem Geol 93:219-230

Esmaeili-Vardanjani M, Shamsipour-Dehkordi R, Eslamo A, Moosaei F, Pazand K (2012) A study of differentiation pattern and rare earth elements migration in geochemical and hydrogeochemical environments of Airekan and Cheshmeh Shotori areas (Central Iran). Environ Earth Sci. doi:10.1007/s12665-012-1773-1

Guo H, Zhang B, Wang G, Shen Z (2010) Geochemical controls on arsenic and rare earth elements approximately along a groundwater flow path in the shallow aquifer of the Hetao Basin, Inner Mongolia. Chem Geol 270:117-125

Herong G, Linhua S, Luwang C, Song C (2011) Rare earth element geochemistry of groundwater from a deep seated sandstone aquifer, northern Anhui province, China. Min Sci Technol (China) 21:477-482

Keasler KM, Loveland WD (1982) Rare earth elemental concentrations in some Pacific Northwest rivers. Earth Planet Sci Lett 61:68-72

Keshavarzi B, Moore F, Mosaferi M, Rahmani F (2011) The Source of Natural Arsenic Contamination in Groundwater, West of Iran. Water Qual Expo Health. doi:10.1007/s12403-011-0051-x

Khademi S (1984) Bam Plain Groundwater Study. Water research institution. Tehran

Kualaksi S, Bau M (2007) Contrasting behaviour of anthropogenic gadolinium and natural rare earth elements in estuaries and the gadolinium input into the North Sea. Earth Planet Sci Lett 260:361-371

Leybourne MI, Goodfellow WD, Boyle DR, Hall GM (2000) Rapid development of negative $\mathrm{Ce}$ anomalies in surface waters and contrasting REE patterns in groundwaters associated with $\mathrm{Zn}-\mathrm{Pb}$ massive sulphide deposits. Appl Geochem 15:695-723

Nguyet VTM (2006) Hydrogeological characterisation and groundwater protection of tropical mountainous karst areas in NW Vietnam. VUB-Hydrologie 48

Pazand K, Hezarkhani A, Ghanbari Y, Aghavali N (2012) Geochemical and quality assessment of groundwater of Marand Basin, East Azarbaijan Province, northwestern Iran. Environ Earth Sci. doi:10.1007/s12665-012-1557-7

Rönnback P, Aström M, Gustafsson J (2008) Comparison of the behaviour of rare earth elements in surface waters, overburden groundwaters and bedrock groundwaters in two granitoidic settings, Eastern Sweden. Appl. Geochem 23:1862-1880 
Seto M, Akagi T (2008) Chemical condition for the appearance of a negative $\mathrm{Ce}$ anomaly in stream waters and groundwaters. Geochem J 42:371-380

Smedley PL, Edmunds WM (2002) Redox patterns and trace element behavior in the East Midlands Triassic Sandstone Aquifer, U.K. Ground Water 40:44-58

Tang J, Johannesson KH (2006) Controls on the geochemistry of rare earth elements along a groundwater flow path in the Carrizo Sand aquifer, Texas, USA. Chem Geol 225:156-171
Taylor SR, McLennan SM (1985) The continental crust: its composition and evolution. Blackwell, Boston, p 312

Willis SS, Johannesson KH (2011) Controls on the geochemistry of rare earth elements in sediments and groundwaters of the Aquia aquifer, Maryland, USA. Chem Geol 285:32-49

Wood SA (1990) The aqueous geochemistry of the Rare-Earth Elements and yttrium. 1. Review of available low-temperature data for inorganic complexes and the inorganic REE speciation of natural waters. Chem Geol 82:159-186 